О. Микитчин, Є. Іванов, У. Маланяк Геопросторовий аналіз...

ISSN 2519-2620. Проблеми геоморфології і палеогеографії...2021. Вип. 1 (12), 39-50

УДК 911.9; 912.43-13; DOI: 10.30970/gpc.2021.1.3456

ГЕОПРОСТОРОВИЙ АНАЛІЗ ЛІСОВИХ УГІДЬ ПЕРЕДГІРНОӤ

І НИЗЬКОГІРНОЇ ЧАСТИН УКРАЇНСЬКИХ КАРПАТ (НА ПРИКЛАДІ

ДРОГОБИЦЬКОГО РАЙОНУ ЛЬВІВСЬКОЇ ОБЛАСТІ)

Оксана Микитчин ${ }^{1}$, Євген Іванов $^{2}$, Уляна Маланяк ${ }^{3}$

${ }^{1}$ Дрогобииький державний педагогічний університет імені Івана Франка, omykytchyn@ukr.net; orcid.org/0000-0002-8146-5947;

${ }^{2}$ Львівський національний університет імені Івана Франка,

yevhen.ivanov@lnu.edu.ua; orcid.org/0000-0001-6847-872X;

${ }^{3}$ Дрогобиџький державний педагогічний університет імені Івана Франка, umalanyak@gmail.com; orcid.org/0000-0002-0128-1401

Анотація. За допомогою дистанційного зондування Землі (на основі космознімків QuickBird) векторизовано лісовий покрив Дрогобицького району Львівської області. На цій основі здійснено геопросторовий аналіз лісових угідь передгірної і низькогірної частин Українських Карпат. 3'ясовано, що частка лісів досліджуваного району є вищою за середній показник лісистості Львівської області й у понад двічі перевищує середній показник лісистості України. Незважаючи на те, що показники лісистості Дрогобицького району є вищими за оптимальні показники для Передкарпаття, лісові угіддя розподілені вкрай нерівномірно. Найзалісненішими є гірські ділянки району з абсолютними висотами 500-1 000 м, рівень заліснення зменшується у напрямі з південного заходу на північний схід. У межах Дрогобицької височини значно зменшуються площі лісів через збільшення густоти населених пунктів і територій впливу Дрогобицької агломерації. У північносхідній ділянці району ліси фактично відсутні, що зумовлено значним сільськогосподарським освоєнням рівнинних територій з переважаючими абсолютними висотами 250-300 м.

3 метою аналізу лісистості досліджуваної території створено та проаналізовано геоінформаційну модель лісистості Дрогобицького району у розрізі адміністративних одиниць. Завдяки моделі вдалося класифікувати адміністративні одиниці за часткою лісових угідь на шість категорій, оскільки у районі спостерігають значні розбіжності в показниках: від абсолютно “безлісих" адміністративних утворень до гірських сільських рад, в яких частка лісовкритих площ становить понад 70 \%. Виокремлено адміністративні одиниці з недостатнім рівнем заліснення, яких у досліджуваному районі практично половина, та з рівнем заліснення нижче середнього по Україні. Зазначено особливості геопросторового розподілу показників заліснення у районі.

Проаналізовано лісистість міських і селищних рад, яка змінюється від значної в Бориславській міській раді до практично відсутніх лісових територій у Меденицькій селищній раді. 3'ясовано причини відмінностей показників та зазначено особливості господарського освоєння територій міських і селищних рад.

Ключові слова: лісистість; дешифрування геоданих; геоінформаційне моделювання; оптимізація природокористування.

\title{
GEOSPATIAL ANALYSIS OF THE FOREST LAND OF FOOTHILL AND LOWLAND PARTS OF THE UKRAINIAN CARPATHIANS (ON THE EXAMPLE OF DROHOBYCH DISTRICT, LVIV REGION) \\ Oksana Mykytchyn, Drohobych Ivan Franko State Pedagogical University; Yevhen Ivanov, Ivan Franko National University of Lviv; Ulyana Malaniak, Drohobych Ivan Franko State Pedagogical University
}

СМикитчин Оксана, Іванов Свген, Маланяк Уляна, 2021. 
О. Микитчин, Є. Іванов, У. Маланяк Геопросторовий аналіз...

Abstract. The forest cover of Drohobych district is vectorized with the help of remote sensing of the Earth based on space images QuickBird. The geospatial analysis of forest lands of the foothills and lowlands of the Ukrainian Carpathians has been carried out. It is found that the proportion of forest throughout the region is higher than the average forest cover of Lviv region and more than doubled the average forest cover of Ukraine. Even though the forest cover of Drohobych district is more than optimal indicators for this natural area, forest land is extremely unevenly distributed. A created schematic map of forest resources has shown that the most forested is the mountainous part of the region with the absolute height between 500-1000 $\mathrm{m}$, which decreases in the direction from southwest to northeast. Forest area significantly decreases at the changeover to Drohobych Upland, because of the extension of the boundaries and areas of influence of the Drogobych agglomeration increasing densities of human settlements. In the northeast section of the region, the forest is almost missing due to the significant agricultural development in the plains with a superior absolute height between 250 $300 \mathrm{~m}$.

For the better analysis of the forest cover of the territory, the geoinformation model of the forest cover of Drohobych district from the perspective of administrative units is created and analyzed. This model allows to classify administrative units according to the proportion of forest land in 6 categories because a considerable variation of indicators is seen in the region. From completely deforested administrative units to rural councils in mountainous areas, where the proportion of forest areas is more than $70 \%$. Administrative units with an insufficient level of reforestation, which are half of all in Drohobych district and with the reforestation level lower than average in Ukraine, are featured. Features of the geospatial distribution of such indicators are noted.

It is analyzed that forest cover in urban and rural councils changes from significant in the town council of Boryslav to almost missing forest areas in the rural council of Medenychi. The reasons for such differences between the indicators are identified and the peculiarities of household land development of the territories that belong to urban and rural councils are stated.

Key words: forest cover; decryption of ERSD; geoinformation modeling; optimization of natural resources.

Вступ. Зростаюче антропогенне навантаження порушує екологічний баланс між природними та антропогенно зміненими складовими природного середовища, що, своєю чергою, активізувало прояв негативних екзогенних процесів та явищ. Упродовж останніх десятиліть природничі науки стрімко екологізувалися, а в питаннях природокористування щораз частіше лунають заклики до раціоналізації використання природних ресурсів. Головним екостабілізуючим чинником природного середовища $є$ лісовий покрив території. Власне йому, у питаннях дослідження антропогенного навантаження, надають першочергового природоохоронного значення, оскільки саме ліси виконують грунтозахисну, водоутримуючу і регуляторну функції, відповідають за формування кліматичних умов та утворення кисню, сприяють збереженню біорізноманіття.

Дрогобицький район розташований у південно-західній частині Львівської області, в межах природних ландшафтів Дрогобицької височини і Східних Бескидів. Власне розташування у передгірній і гірській місцевостях зумовлює різний характер господарювання. Незважаючи на те, що досліджувану територію зачислено до п'яти адміністративних районів Львівської області, у яких показник заліснення вищий від рекомендованого для цієї природної зони, лісові угіддя розташовані нерівномірно. Отож належність Дрогобицького району до категорії територій забезпечених лісовими ресурсами, робить його вразливим до 
О. Микитчин, Є. Іванов, У. Маланяк Геопросторовий аналіз...

лісогосподарського використання, яке часто $є$ нераціональним. Саме тому здійснення геопросторового аналізу розподілу лісових угідь у районі дослідження $\epsilon$ вкрай актуальним завданням.

Питання оптимізації лісистості піднімали ще у працях радянських учених К. Лосицького, А. Миховича і А. Молчанова, розрахунок нормативних показників лісистості України для рівнинної частини здійснено Ю. Бяловичем (Бялович, 1972), для адміністративних одиниць - А. Миховичем і С. Генсіруком (Генсірук, Копій і Іваницький, 1999; Ткач і Мєшкова, 2008; Чабанчук, 2018). В умовах сучасності вчення щодо оптимізації лісистості досліджуваного регіону переосмислено у працях В. Ткача, В. Мєшкової, В. Олійника і О. Ткачук (Ткач і Мєшкова, 2008; Олійник, 2013; Олійник і Ткачук, 2016). Зокрема, проблеми оптимізації лісистості Західного регіону України детально вивчені С. Генсіруком і Л. Копієм (Генсірук та ін., 1999).

Найкращим науково-методичним підходом для збирання, опрацювання i візуалізації геопросторових даних та подальшого їхнього аналізу вважають геоінформаційні системи (ГІС), широко залучені під час дослідження лісових ресурсів. Власне на застосуванні ГІС-технологій грунтуються дослідження втрат лісистості території (Круглов та ін., 2013; Часковський і Гриник, 2020), динаміки лісового покриву (Миронюк і Білоус, 2017), впливу лісових угідь на гідрологічні і грунтові умови (Олійник, 2013; Олійник і Ткачук, 2014; Часковський, Карабчук i Іванюк, 2019), геопросторовий аналіз стану лісів (Бурштинська, Поліщук i Ковальчук, 2013; Жолобак, 2010), оцінки стійкості форм рельєфу до антропогенного навантаження (Ковальчук та ін., 2008 б). Нами накопичено досвід геоінформаційного картографування і моделювання функціонування та стану різнофункціональних природно-господарських систем досліджуваного регіону (Ковальчук та ін., 2008 а; Ковальчук, Іванов і Андрейчук, 2004).

Дослідження стану лісових ресурсів Західного регіону України найчастіше здійснюють у розрізі адміністративних областей або природних зон. Значно менше уваги приділено вивченню цього питання на локальному рівні. Доволі актуальним $\epsilon$ дослідження передгірних територій, які характеризуються різкою зміною орографічних умов та за значних середніх показників заліснення мають чималі безлісі території. Власне одним $з$ таких передгірних районів Львівської області є Дрогобицький район, який унаслідок давнього господарського освоєння характеризується вкрай нерівномірним розподілом лісових ресурсів.

Метою роботи є геопросторовий аналіз лісистості Дрогобицького району Львівської області на основі геоінформаційної моделі лісових ресурсів, створеної за результатами дешифрування даних дистанційного зондування Землі.

Методика дослідження. Вихідними матеріалами дослідження є космознімки високої роздільної здатності, великомасштабні топографічні карти та цифрова модель рельєфу на основі даних космічного радарного знімання SRTM. Для виконання поставлених завдань використано програмний ГIC-пакет ArcGIS 10.4. Зокрема, векторизовано лісові масиви у полігональному тематичному шарі. На основі оверлейного аналізу дешифрованого лісового покриву і цифрової моделі рельєфу здійснено геопросторовий аналіз лісових угідь Дрогобицького району.

Для аналізу лісистості досліджуваної території використано два підходи: перший грунтується на методі рівновеликих квадратів (у нашому випадку $1 \times 1$ км) з використанням функції Create Fishnet 3 набору інструментів управління 
О. Микитчин, Є. Іванов, У. Маланяк Геопросторовий аналіз...

даними Data Management із зазначенням вихідної координати для побудови сітки, одиниць виміру, розмірів комірок; другий має прикладний характер, оскільки в основу розрахунку покладено адміністративно-територіальні одиниці району - міські, селищні і сільські ради. Виокремлення досліджуваних одиниць здійснено у команді Intersect 3 набору інструментів оверлейного аналізу (Analysis Tools/Overlay). У результаті отримано зведену таблицю лісистості території, у якій за допомогою індексного поля (ідентифікатора адміністративної одиниці) присвоєно цю інформацію для окремого квадрату сітки чи адміністративної одиниці (Ковальчук, Андрейчук і Іванов, 2010).

Результати та обговорення. Аналіз цифрової моделі Дрогобицького району засвідчив, що понад чверть території (28,8 \%) зайнято гірськими масивами, які розташовані у південній і південно-західній частинах району та представлені Східними Бескидами 3 абсолютними висотами до 991,0 м (рис. 1). Низькогірні хребти простягаються 3 північного заходу на південний схід і мають пересічні висоти від 500 до 700 м.

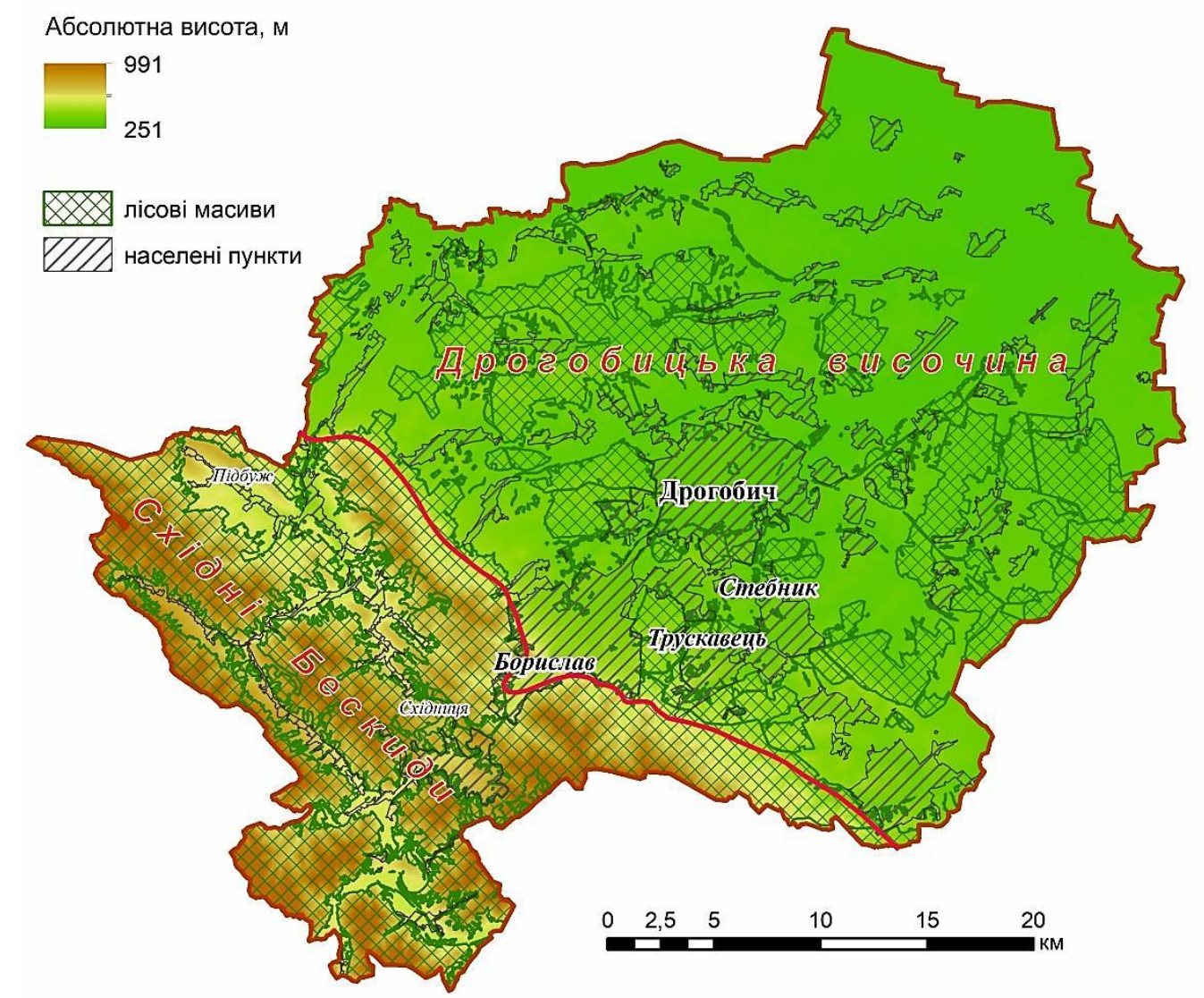

Рис. 1. Цифрова модель рельєфу території Дрогобицького району із розміщеними лісовими угіддями

Fig. 1. Digital elevation model of Drohobych district with located forest lands 
О. Микитчин, Є. Іванов, У. Маланяк Геопросторовий аналіз...

У межах досліджуваної території Східні Бескиди є системою паралельних асиметричних хребтів, які розчленовані поздовжніми вузькими і поперечними широкими долинами річок й міжгірними улоговинами. За геоструктурними особливостями низькогір'я належить до Скибової зони та складається, здебільшого, з карпатського флішу. Тут переважають букові ліси із домішкою ялини та ялиці, а також похідні ялинники і післялісові червонокострицеві луки на буроземах середньоглибоких грунтів (Кагало, 2006).

Решту території району зайнято Дрогобицькою денудаційно-акумулятивноерозійною височиною 3 домінуючими абсолютними висотами 250-350 м, яку розділяють широкі долини Бистриці Підбузької і Тисмениці на три співрозмірні частини, що паралельними смугами простягаються у бік Дністра (див. рис. 1). У межах височини домінують увалисто-хвилясті форми рельєфу з розгалуженою яружно-балковою мережею. Геоструктурно вона пов'язана з Передкарпатським прогином та складена лесоподібними суглинками і галечниками. На терасах Дрогобицької височини сформувалися дерново-підзолисті поверхнево-оглеєні грунти, у долинах - дерново-глейові лучні грунти. У рослинному покриві переважають мішані, буково-ялинові, дубово-вільхові ліси та різнотравнозлакові луки (Штойко, 2006).

На основі створеної геоінформаційної моделі обчислено, що лісистість Дрогобицького району становить 38,4 \% (середня лісистість по Україні -15,9\%). Площа лісового фонду сягає понад $500 \mathrm{kм}^{2}$. Аналіз створеної моделі вказав на регіональні особливості розподілу лісових угідь по території району. Чіткі відмінності спостерігаємо у розрізі природних (ландшафтних) одиниць, а саме в межах Дрогобицької височини і Східних Бескидах (див. рис. 1; табл. 1). Зокрема, у передгірній частині досліджуваного району середній показник лісистості становить $24,95 \%$, а в низькогірній - суттєво зростає до 71,63 \%.

Таблиця 1. Розподіл лісистості у передгірній і низькогірній частинах Українських Карпат

Table 1. Distribution of forest cover in the foothills and lowlands of the Ukrainian Carpathians

\begin{tabular}{|l|c|c|c|}
\hline \multicolumn{1}{|c|}{ Природні виділи } & $\begin{array}{c}\text { Площа виділів, } \\
\text { км}^{2}\end{array}$ & $\begin{array}{c}\text { Площа лісових } \\
\text { масивів, км }\end{array}$ & Лісистість, \% \\
\hline \multicolumn{3}{|c|}{ У розрізі природних (ландмафтнии) одинищь } \\
\hline Дрогобицька височина & 927,9 & 231,5 & 24,95 \\
\hline Східні Бескиди & 375,8 & 269,2 & 71,63 \\
\hline \multicolumn{4}{|c|}{ У розрізі адміністративних одинищь } \\
\hline Дрогобицька височина & 969,7 & 269,0 & 27,74 \\
\hline Східні Бескиди & 334,0 & 231,7 & 69,36 \\
\hline
\end{tabular}

На вирівняних ділянках Дрогобицької височини у північній та північносхідній частині району з абсолютними висотами 250-300 м ліс практично відсутній. Таку ситуацію пояснює тривале сільськогосподарське освоєння цих ділянок. Натомість гірські території з абсолютними висотами понад 500 м $є$ найзалісненішими. Ділянки без лісових угідь $є$ у річкових долинах, які зайняті населеними пунктами. Щодо передгірної частини району зазначимо, що лісові 
угіддя розташовані там фрагментарно, переважно на підвищених ділянках межиріч. Суттєво менше лісових масивів виявлено в межах Дрогобицької агломерації.

Аналогічну ситуацію спостерігаємо за розрахунку лісистості території методом рівновеликих квадратів (рис. 2). Лісистість зростає у двох напрямах: 3 північного сходу на південний захід та із віддаленістю від населених пунктів. Безлісі ділянки $є$ у нижніх течіях річок та центрах великих населених пунктів. Найлісистішою $є$ південна, західна і південно-західна частини району (понад 50$60 \%$ території). Нижчі показники лісистості властиві центральній і східній частинам.

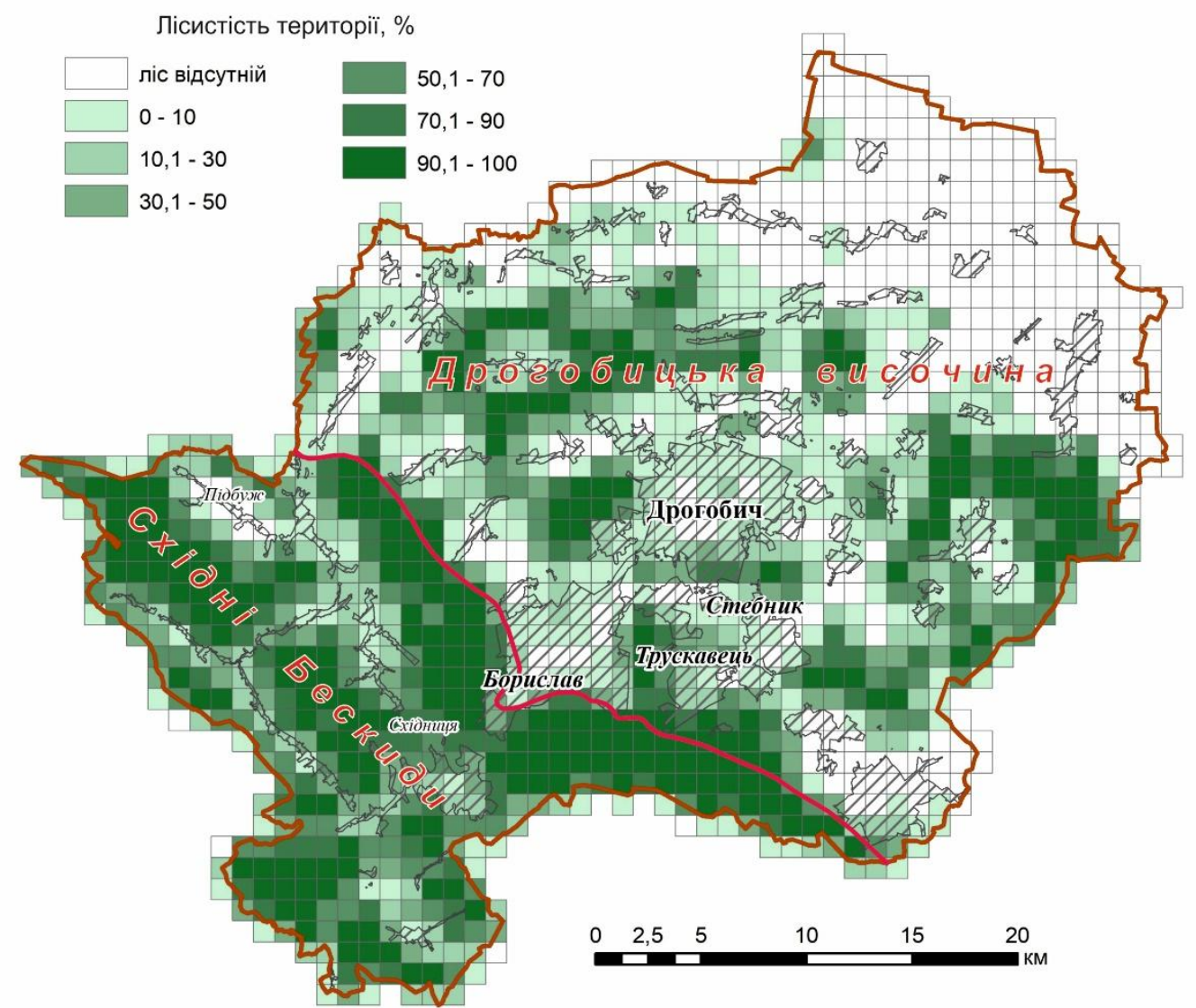

Рис. 2. Лісистість території Дрогобицького району, розрахована методом рівновеликих квадратів

Fig. 2. Forest cover of Drohobych district, calculated by the method of equal squares

За допомогою геоінформаційного моделювання розраховано рівень лісистості Дрогобицького району у розрізі адміністративно-територіальних одиниць (рис. 3). У Літинській, Опорівській і Ріпчицькій сільських радах лісові угіддя відсутні. Дуже низькі показники лісистості (1-5\%) властиві сусіднім до них Грушівській і Волощанській сільським радам. Майже чверть території району 
має нижчий від середнього по Україні показник лісистості, а понад третину території заліснено нижче оптимального для передкарпатських ландшафтів рівня. Таку ситуацію пояснюємо активною сільськогосподарською діяльністю на вирівняних ділянках району, що зростає із віддаленістю від районного центру (за винятком гірської території).

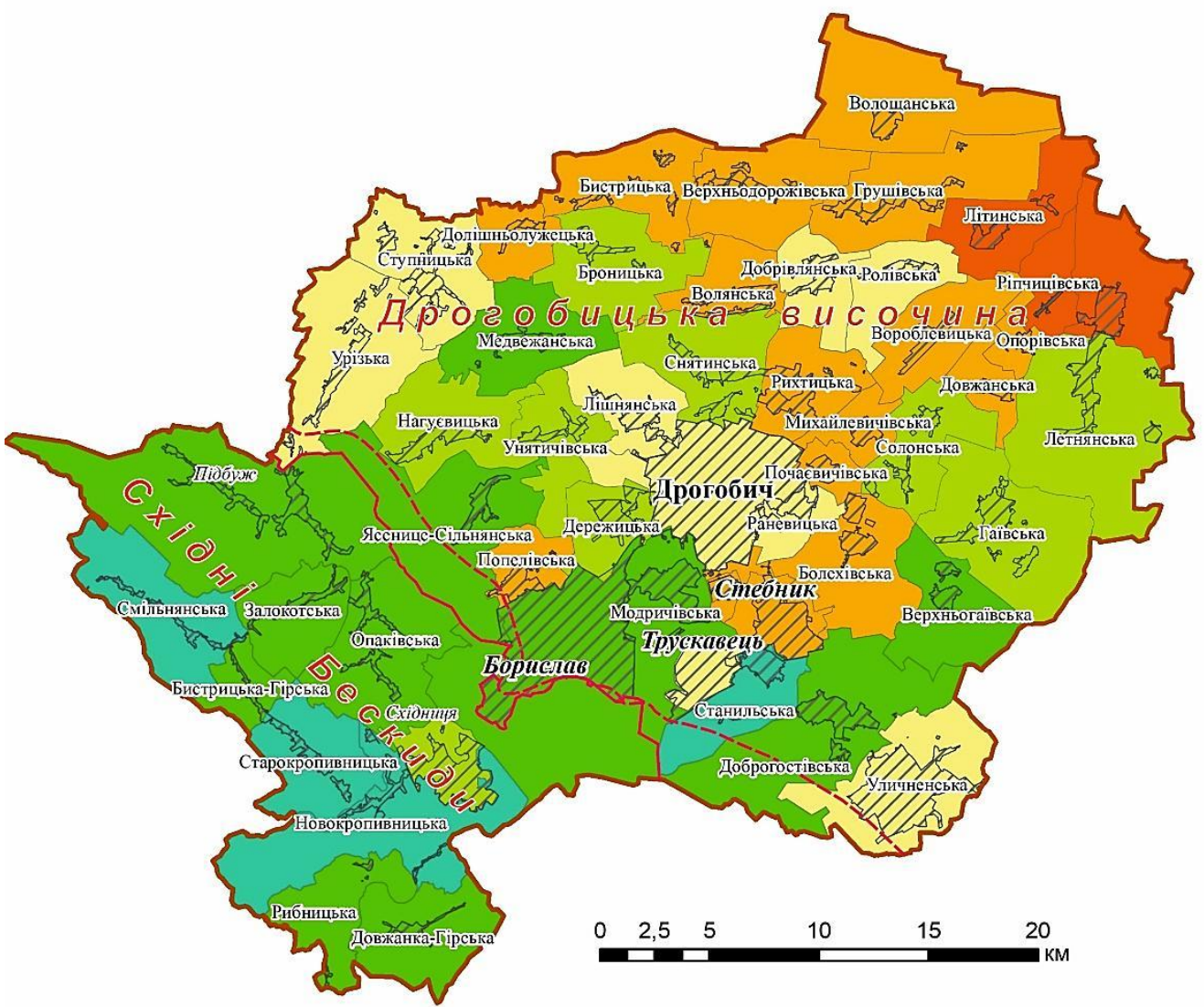

Лісистість території, \%

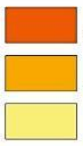

ліс відсутній

до 15,9 (нижче середнього рівня країни)

16 - 30 (нижче необхідного рівня)

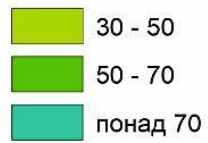

Рис. 3. Лісистість території Дрогобицького району у розрізі адміністративних одиниць

Fig. 3. Forest cover of Drohobych district in terms of administrative units

Відчутні відмінності у лісистості адміністративних одиниць також зумовлені їхнім розміщенням у передгірній чи низькогірній частинах Українських Карпат. Нами розраховано показники лісистості у розрізі адміністративних одиниць досліджуваного району (див. табл. 1). Зазначимо, що межі природних (на карті пунктирною лінією) та адміністративних (на карті суцільною лінією) виділів не 
збігаються (див. рис. 3). Саме цим зумовлено деякі невідповідності у значеннях лісистості для адміністративних виділів, порівняно з природними утвореннями. Наприклад, для адміністративних одиниць у межах Дрогобицької височини середній показник лісистості становить $27,74 \%$, а в межах Східних Бескидів $69,36 \%$.

Високі показники лісистості (50-70 \%) характерні багатьом адміністративним одиницям південної, західної та південно-західної частин району. Здебільшого це гірські і передгірні території, де орографічними умовами ускладнено проведення сільського господарства, що є головним способом природокористування району. Максимальні показники лісистості (понад 70 \%) спостерігаємо у Смільнянській, Старокропивницькій, Станильській і Новокропивницькій сільських радах. Таку закономірність розподілу зумовило розташування цих сільських рад у віддалених від районного центру карпатських місцевостях та рекреаційній зоні Трускавця, під вплив якої потрапляє Станильська сільська рада.

Серед міських і селищних рад за лісовим покривом лідирує Бориславська міська рада $(59,66 \%)$, що зумовлено розташуванням у ії межах ландшафтного заказника місцевого значення "Бориславський” площею 2 048,8 га. На другому місці - Східницька селищна рада (34,30 \%), у межах якої розміщено ландшафтний парк Пантелеймона Цілителя. У Дрогобицькій міській раді 19,96 \% території зайняті парками: Культури і відпочинку, Степана Бандери, імені Героїв Небесної Сотні, Новонароджених.

У місті-курорті Трускавець 17,78 \% земельних угідь засаджено парковими насадженнями (Курортний парк і парк “Підгір'я”). Неподалік від північної околиці Трускавця розміщена ботанічна пам'ятка природи місцевого значення “Два вікові дуби”. Найменше лісовими ресурсами забезпечено м. Стебник (4,0 \%), що пояснюємо значними площами земель, відведеними під сільськогосподарські угіддя, постмайнінговими територіями, зокрема ліквідованими рудниками i збагачувальною фабрикою та діючим хвостосховищем.

Висновки. Геопросторовий аналіз заліснення Дрогобицького району засвідчив, що лісові ресурси, незважаючи на достатній для передкарпатських ландшафтів показник лісистості розташовані нерівномірно. Найскладніша ситуація у північній і північно-східній частині району дослідження, де лісових угідь вкрай недостатньо та активно розорюють території. У цій частині району слід здійснювати роботи з лісовідновлення і лісонасадження, що сприятиме зниженню рівня антропогенного навантаження на природне середовище.

Передгірна частина Дрогобицького району, що простягається 3 північного заходу на південний схід, має вищі показники лісистості, хоча геопросторовий аналіз розподілу лісових угідь доводить, що необхідно більше уваги приділяти підвищенню залісненості водоохоронних зон уздовж основних водних артерій досліджуваної території.

Значні показники лісистості властиві гірській і передгірній рекреаційним частинам Дрогобицького району. Власне за рахунок високих показників у межах цих місцевостей сформований середній показник лісистості у районі дослідження. Бескидські ліси відіграють велике водоохоронне значення, отож зменшення лісистості цих територій може спричинити негативні явища.

Досліджуваний район потребує раціонального ведення лісового господарства, активного лісонасадження і лісовідновлення, отож у перспективі важливим $€$ 
О. Микитчин, Є. Іванов, У. Маланяк Геопросторовий аналіз...

створення оптимальної моделі заліснення території Дрогобицького району, яка даватиме змогу суттєво зменшити рівень антропогенного навантаження на складові природного середовища. 3 метою підвищення лісистості до оптимального рівня лісогосподарським підприємствам слід розширити комплекс робіт 3 відтворення лісів. Для поліпшення якісного складу лісів, їхнього оздоровлення та посилення лісозахисних властивостей щороку слід здійснювати роботи на загальній площі понад 500 га, у тім числі лісівничі догляди за молодняками на площі 100 га.

\section{СПИСОК ВИКОРИСТАНОЇ ЛІТЕРАТУРИ}

Бурштинська X. В. Дослідження методів класифікації лісів з використанням космічних знімків високого розрізнення / Х. В. Бурштинська, Б. В. Поліщук, О. Ю. Ковальчук // Геодезія, картографія і аерофотознімання. - 2013. Вип. 78. - С. 101-110.

Бяллович Ю. П. Нормативы оптимальной лесистости равнинной части УССР / Ю. П. Бяллович // Лесоводство и агролесомелиорация. - 1972. - Вып. 28. C. 54-65.

Генсірук С. А. Збереження біорізноманіття лісових екосистем шляхом формування оптимальної лісистості в агроландшафтах України / С. А. Генсірук, Л. І. Копій, С. М. Іваницький // Наук. вісн. УкрДЛТУ. - 1999. - Вип. 10.1. - С. 53-56.

Жолобак Г. М. Вітчизняний досвід супутникового моніторингу лісових масивів України / Г. М. Жолобак // Космічна наука і технологія. - 2010. - Вип. 16 (3). C. $46-54$.

Кагало О. О. Бескиди східні // Енциклопедія Сучасної України : електронна версія [веб-сайт]. - Київ : Інститут енциклопедичних досліджень НАН України, 2006. - URL: http://esu.com.ua/search_articles.php?id=39549.

Ковальчук I. Картографічне i геоінформаційне моделювання природногосподарських систем Західного регіону України / I. Ковальчук, Є. Іванов, Ю. Андрейчук, Н. Лобанська, В. Клюйник // Картографія та вища школа. 2008. - Вип. 13. - С. 48-59.

Ковальчук I. П. Геоінформаційне забезпечення створення атласу земельних ресурсів сільської ради / І. П. Ковальчук, Ю. М. Андрейчук, Є. А. Іванов // Фізична географія та геоморфологія. - 2010. - Вип. 4 (61). - С. $79-89$.

Ковальчук І. П. Моделювання стану природно-антропогенних систем 3 використанням ГІС-технологій / I. П. Ковальчук, Є. А. Іванов, Ю. М. Андрейчук // Геодезія, картографія і аерофотознімання. - 2004. Вип. 65. - С. 105-110.

Ковальчук І. П. Оцінка стійкості параметрів рельєфу басейнів малих річок до антропогенного навантаження / I. П. Ковальчук, Ю. М. Андрейчук, Є. А. Іванов, О. І. Микитчин // Гідрологія, гідрохімія і гідроекологія. - 2008. T. 14. - C. 221-231.

Круглов І. Динаміка лісистості Українських Карпат протягом 1988-2007 років : геоекологічний аналіз засобами геоматики / I. Круглов, Т. Кюммерле, О. Часковський та ін. // Вісн. Львів. ун-ту. - 2013. - Сер. геогр. Вип. 46. C. 218-233. 
Миронюк В. В. Узгодженість оцінок площі лісів за даними глобальної карти змін лісового покриву i мультиспектральних супутникових знімків / В. В. Миронюк, А. М. Білоус // Наук. вісн. НЛТУ України. - 2017. - Вип. 27 (5). - C. 38-42. - https://doi.org/10.15421/40270507.

Олійник В. С. Гідрологічна роль лісів Українських Карпат : монографія / В. С. Олійник. - Івано-Франківськ : НАІР, 2013. - 232 с.

Олійник В. С. Лісовий покрив річкових басейнів Передкарпаття та його стокорегулювальна роль / В. С. Олійник, О. М. Ткачук // Наук. вісн. НЛТУ України. - 2014. - Вип. 24 (9). - С. 26-32.

Олійник В. С. Шляхи оптимізації лісистості Передкарпаття / В. С. Олійник, О. М. Ткачук // Наукові праці Лісівничої академії наук України. - 2016. Вип. 14. - С. 79-84. - https://doi.org/10.15421/411610.

Ткач В. П. Сучасні проблеми оптимізації лісистості України / В. П. Ткач, В. Л. Мєшкова // Лісівництво і агролісомеліорація. - 2008. - № 113. - С. 8-15.

Чабанчук В. Ю. Еколого-географічний аналіз лісових ландшафтів Рівненської області : дис. ... канд. геогр. наук / В. Ю. Чабанчук ; Східноукраїнський національний університет імені Лесі Українки. - Луцьк, 2018.

Часковський О. Г. Зміни лісового вкриття Українських Карпат за період 19842016 років / О. Г. Часковський, Д. Ю. Карабчук, А. П. Іванюк // Наук. вісн. НЛТУ України. - 2019. - Вип. 29 (2). - С. 9-14. https://doi.org/10.15421/40290201.

Часковський О. Г. Оцінювання втрат лісового покриву Українських Карпат дистанційними методами за матеріалами відкритих джерел супутникової інформації / О. Г. Часковський, Г. Г. Гриник // Наук. вісн. НЛТУ України. 2020. - Вип. 30 (1). - С. 66-73. - https://doi.org/10.36930/40300111.

Штойко П. І. Дрогобицька височина // Енциклопедія Сучасної України: електронна версія [веб-сайт]. - Київ : Інститут енциклопедичних досліджень НАН України, 2006. URL: http://esu.com.ua/search_articles.php?id=21812.

\section{REFERENCES}

Biallovych, Yu. P. (1972) Normativy optimal'noj lesistosti ravninnoj chasti USSR [Standards for the optimal forest cover of the plain part of the Ukrainian SSR]. In Lesovodstvo i agrolesomelioraciya, 28, 54-65. (In Russian).

Burshtynska, H. V., Polishchuk, B. V., Kovalchuk, O. Yu. (2013). Doslidzhennia metodiv klasyfikatsii lisiv $\mathrm{z}$ vykorystanniam kosmichnykh znimkiv vysokoho rozriznennia [Investigation of forest classification methods using high resolution space images]. In Heodeziia, kartohrafiia i aerofotoznimannia, 78, 101-110. (In Ukrainian).

Chabanchuk, V. Yu. (2018). Ekoloho-heohrafichnyi analiz lisovykh landshaftiv Rivnenskoi oblasti [Ecological-geographical analysis of forest landscapes of Rivne region]. Dyser. ... kand. heohr. nauk (Dissertation for the degree of the Candidate of Geographical Sciences). Lesia Ukrainka East Ukrainian National University, Lutsk. (In Ukrainian).

Chaskovskyy, O. H., Hrynyk, H. H. (2020). Otsiniuvannia vtrat lisovoho pokryvu Ukrainskykh Karpat dystantsiinymy metodamy za materialamy vidkrytykh dzherel suputnykovoi informatsii [Estimation of losses of forest cover of the Ukrainian 
О. Микитчин, Є. Іванов, У. Маланяк Геопросторовий аналіз...

Carpathians by remote methods based on the materials of open sources of satellite information]. In Nauk. visn. NLTU Ukrainy, 30 (1), 66-73. https://doi.org/10.36930/40300111 (In Ukrainian).

Chaskovskyy, O. H., Karabchuk, D. Yu., Ivaniuk, A. P. (2019). Zminy lisovoho vkryttia Ukrainskykh Karpat za period 1984-2016 rokiv [Forest disturbance in the Ukrainian Carpathians from 1984 to 2016]. In Nauk. visn. NLTU Ukrainy, 29 (2), 9-14. https://doi.org/10.15421/40290201 (In Ukrainian).

Gensiruk, S. A., Kopiy, L. I., Ivanitsky, S. M. (1999). Zberezhennia bioriznomanittia lisovykh ekosystem shliakhom formuvannia optymalnoi lisystosti $\mathrm{V}$ ahrolandshaftakh Ukrainy [Conservation of biodiversity of forest ecosystems through the formation of optimal forest cover in agricultural landscapes of Ukraine]. In Nauk. visn. UkrDLTU, 10 (1), 53-56. (In Ukrainian).

Kahalo, O. O. (2006). Beskydy skhidni [Beskyds Eastern]. In Entsyklopediia Suchasnoi Ukrainy. Kyiv: Instytut entsyklopedychnykh doslidzhen NAN Ukrainy. URL: http://esu.com.ua/search_articles.php?id=39549 (In Ukrainian).

Kovalchuk, I. P., Andreichuk, Yu. M., Ivanov, Ye. A., Mykytchyn, O. I. (2008) Otsinka stiikosti parametriv reliefu baseiniv malykh richok do antropohennoho navantazhennia [Assessment of the stability of the parameters of the relief basins of small rivers to anthropogenic pressure]. In Hidrolohiia, hidrokhimiia $i$ hidroekolohiia, 14, 221-231. (In Ukrainian).

Kovalchuk, I. P., Andreychuk, Yu. M., Ivanov, E. A. (2010). Heoinformatsiine zabezpechennia stvorennia atlasu zemelnykh resursiv silskoi rady [Geoinformation solutions for village council land resources atlas creation]. In Fizychna heohrafiia ta heomorfolohiia, 4 (61), 79-89. (In Ukrainian).

Kovalchuk, I. P., Ivanov, Ye. A., Andreichuk, Yu. M. (2004) Modeliuvannia stanu pryrodno-antropohennykh system z vykorystanniam HIS-tekhnolohii [Modeling the state of natural and anthropogenic systems using GIS technologies]. In Heodeziia, kartohrafiia i aerofotoznimannia, 65, 105-110. (In Ukrainian).

Kovalchuk, I., Ivanov, Ye., Andreichuk, Yu., Lobanska, N., Kliuinyk, V. (2008) Kartohrafichne i heoinformatsiine modeliuvannia pryrodno-hospodarskykh system Zakhidnoho regionu Ukrainy [Cartographic and geoinformation modeling of natural economic systems of the Western region of Ukraine]. In Kartohrafiia ta vyshcha shkola, 13, 48-59. (In Ukrainian).

Kruhlov. I., Kuemmerle, T., Chaskovskyy, O., Knorn, J., Radeloff, V., Hostert, P. (2013). Dynamika lisystosti Ukrainskykh Karpat protiahom 1988-2007 rokiv: heoekolohichnyi analiz zasobamy heomatyky [Forest cover dynamics in the Ukrainian Carpathians during 1988-2007: A geomatics-based geoecological analysis]. In Visn. Lviv. un-tu. Ser. heohr., 46, 218-233. (In Ukrainian).

Myronyuk, V. V., Bilous, A. M. (2017). Uzghodzhenist otsinok ploshchi lisiv za danymy hlobalnoi karty zmin lisovoho pokryvu i multyspektralnykh suputnykovykh znimkiv [Consistency of forest area estimates according to global forest change data and multispectral satellite image]. In Nauk. visn. NLTU Ukrainy, 27 (5), 38-42, https://doi.org/10.15421/40270507 (In Ukrainian).

Oliinyk, V. S. (2013). Hidrolohichna rol lisiv Ukrainskykh Karpat [Hydrological role of forests of the Ukrainian Carpathians]. Ivano-Frankivsk: NAIR. (In Ukrainian).

Oliinyk, V. S., Tkachuk, O. M. (2014). Lisovyi pokryv richkovykh baseiniv Peredkarpattia ta yoho stokorehuliuvalna rol [Forest cover of river basins of 
Precarpathia and its flow-regulating role]. In Nauk. visn. NLTU Ukrainy, 24 (9), 26-32. (In Ukrainian).

Oliinyk, V. S., Tkachuk, O. M. (2016). Shliakhy optymizatsii lisystosti Peredkarpattia [Ways to optimize the forest cover of Precarpathia]. In Naukovi pratsi Lisivnychoi akademii nauk Ukrainy, 14, 79-84. https://doi.org/10.15421/411610 (In Ukrainian).

Shtoiko, P. I. (2006). Drohobytska vysochyna [Drohobych Upland]. In Entsyklopediia Suchasnoi Ukrainy. Kyiv: Instytut entsyklopedychnykh doslidzhen NAN Ukrainy. URL: http://esu.com.ua/search articles.php?id=21812 (In Ukrainian).

Tkach, V. P., Meshkova, V. L. (2008). Suchasni problemy optymizatsii lisystosti Ukrainy [Modern problems of optimization of Ukrainian forest cover]. In Lisivnytstvo i ahrolisomelioratsiia, 113, 8-15. (In Ukrainian).

Zholobak, H. M. (2010). Vitchyznianyi dosvid suputnykovoho monitorynhu lisovykh masyviv Ukrainy [Domestic experience of satellite monitoring over forest stands in Ukraine]. In Kosmichna nauka i tekhnolohiia, 16 (3), 46-54. (In Ukrainian).

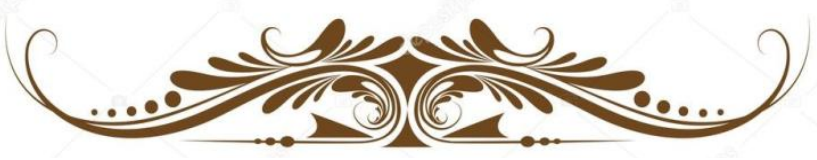

